septicaemia, meningitis, pneumococcal infections, etc., may at times be associated with toxic haemoglobinuria as a result of an acute haemolytic crisis.

One is struck by the dramatic onset of favism: it can result in the destruction of more than $75 \%$ of the red cells in the blood within 24 hours. However, the response to blood transfusion is nothing short of miraculous. Favism can recur, and the only prevention is to refrain from eating the broad-bean.

\section{S. MANSOOR, M.D.} Acre, Israel.

\section{Treatment of Rheumatoid Arthritis with Organic Copper Compounds}

Improvement in cases of rheumatoid arthritis treated with an organic compound of copper was reported by Forestier and Certonciny (1946), who referred to the previous work of Fenz (1941) in Germany.

The drug, cuproallyl-thiourea-sodium benzoate, is a yellowish-brown crystalline powder containing $19 \%$ of copper and readily soluble in water. The solution is irritating to the tissues and must be administered intravenously. It accumulates in the liver and to a lesser extent in the spleen, kidneys, lungs, heart, and brain. Excretion is mainly by the intestine and is slow, continuing after administration has ceased.

Forestier and Certonciny, following the German workers, at first used small doses of 0.01 to $0.1 \mathrm{~g}$., averaging $1 \mathrm{~g}$. for a course. Finding that the drug was well tolerated, they increased the dose, giving 0.25 to $0.5 \mathrm{~g}$. twice weekly, administering up to $5 \mathrm{~g}$. in a course. Doses were given intravenously, dissolved in $10 \mathrm{ml}$. of sterile distilled water Courses of treatment were repeated at the end of a month and again at intervals of two or three months. No toxic effects were encountered.

Results were better with the higher dosage. Out of a series of 40 cases improvement was noted in $80 \%$, the result being excellent in $15 \%$. But most of the good results were in early cases of less than one year's duration.

A trial by Tyson et al. (1950) in a series of 20 cases was not encouraging. Kuzell et al. (1951), in a group of 31 patients, failed to confirm the claims made for the drug: at the best they thought there might be a slight therapeutic effect in cases associated with psoriasis.

Through the courtesy of Lumière a small quantity of the preparation was obtained and tried in a few cases with indefinite results.

May \& Baker Ltd. then synthesized two compounds: "alcuprin" (sodium $m$-(N-allylcuprothiocarbamide) benzoate) for intravenous use, and " cuprimyl " (a copper complex of 8-hydroxyquinoline bis-(diethylamine sulphonate)) for intramuscular injection. A trial was begun with these on a group of well-established cases of rheumatoid arthritis, in four of which chrysotherapy had been given. For descriptive purposes the cases are graded as follows: grade 1 , physical signs slight ; grade 2 , well-marked physical signs but general condition good; grade 3, extensive physical signs with wasting and poor general condition; grade 4, extensive physical signs with poor general condition, wasting, and crippling.

\begin{tabular}{|c|c|c|c|c|c|c|c|}
\hline \multirow{2}{*}{$\begin{array}{l}\text { Case } \\
\text { No. }\end{array}$} & \multirow{2}{*}{ Sex } & \multirow{2}{*}{ Age } & \multirow{2}{*}{$\begin{array}{c}\text { Duration } \\
\text { of } \\
\text { Illness }\end{array}$} & \multirow{2}{*}{ Grade } & \multicolumn{2}{|c|}{$\begin{array}{l}\text { Sedimentation } \\
\text { Rate }\end{array}$} & \multirow{2}{*}{ Result } \\
\hline & & & & & Before & After & \\
\hline 1 & $\mathbf{M}$ & 24 & 3 years & 1 & 6 & 3 & $\begin{array}{c}\text { Slightly } \\
\text { improved }\end{array}$ \\
\hline $\begin{array}{r}2 \\
3 \\
4 \\
5 \\
6 \\
7 \\
8 \\
9 \\
10\end{array}$ & $\begin{array}{l}\mathbf{M} \\
\mathbf{M} \\
\mathbf{F} \\
\mathbf{F} \\
\mathbf{M} \\
\mathbf{F} \\
\mathbf{M} \\
\mathbf{F} \\
\mathbf{M}\end{array}$ & $\begin{array}{l}41 \\
62 \\
35 \\
57 \\
43 \\
45 \\
52 \\
65 \\
45\end{array}$ & 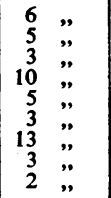 & $\begin{array}{l}1 \\
1 \\
2 \\
2 \\
3 \\
3 \\
3 \\
3 \\
4\end{array}$ & $\begin{array}{l}8 \\
5 \\
22 \\
20 \\
18 \\
37 \\
25 \\
27 \\
87\end{array}$ & $\begin{array}{r}5 \\
12 \\
21 \\
25 \\
9 \\
38 \\
25 \\
75 \\
100\end{array}$ & $\begin{array}{l}\text { Unchanged } \\
, " \\
. " \\
\text { Worse } \\
\text { Unchanged }\end{array}$ \\
\hline
\end{tabular}

All patients had two courses of treatment, each course comprising 10 doses of $0.25 \mathrm{~g}$. of alcuprin with a total of $2.5 \mathrm{~g}$., or $0.5 \mathrm{~g}$. of cuprimyl with a total of $5 \mathrm{~g}$. Patients were under observation for three months before treatment and one year after. Toxic effects were not observed. The results are set out in the Table.

No therapeutic effect was demonstrated in the group The trial was an exacting one on a selected group from which early cases had been excluded, and in consequence a sustained improvement could with confidence have been attributed to the drug. Early cases were excluded because the fluctuating course of some and the occasional occurrence of spontaneous remissions make assessment difficult ; also the early stage of the disease may be modified by a number of drugs which have no lasting effect. Though a further trial in this early type of case seems worth while, assessment is difficult.

Two patients (Cases 3 and 5) had psoriasis, which was not influenced by the drug.

I am indebted to May \& Baker Ltd. for ample supplies of both drugs for this trial.

\section{T. J. O'ReILLY, M.D.} Dublin Rheumatism Clinic.

\section{REFERENCES}

Fenz, E. (1941) Münch, med. Wschr., 88, 1101

Forestier, J., and Certonciny, A. (1946). Presse méd., 54, 884.

Kuzell, W. C., Schaffarzick, R. W., Mankle, E. A., and Gardner, G. M (1951). Ann. Rev. Med., 2, 390.

Tyson. T. L., Holmes, H. H., and Ragen, C. (1950). Amer. J. med. Sct. 220, 418 .

\section{Fat Embolism in Thoracic Operations}

Fat embolism as a complication of operative procedures has been described in association with orthopaedic and abdominal surgery, but little reference has been made to its possible occurrence in thoracic operations. In view of the growing importance of cardiac surgery it is felt that the following observations are worthy of record.

Over the past two years small fragments of lung tissue from patients subjected to mitral valvotomy have been submitted for routine histological examination. During study of these biopsy specimens in two cases the large and medium-sized pulmonary arteries were found to contain bone marrow. Frozen sections stained by Scharlach $\mathbf{R}$ were employed on all subsequent lung biopsies from valvotomy patients, and in 4 out of 24 a minor degree of fat embolism was noted. Similar studies were made on pneumonectomy and lobectomy specimens. In one case bone marrow was present in the major pulmonary arteries, and in 10 out of 17 cases a slight degree of fat embolism was noted in frozen sections.

The occurrence of fat embolism in valvotomy patients is not altogether surprising, since the operative procedure entails continuous rib retraction and considerable trauma is possible. Fractures have even been recorded in some cases. The actual severance of ribs during pneumonectomy and other thoracic operations accounts for the higher incidence of fat embolism in this group. Vance (1931) has suggested that a slight degree of fat embolism cannot always be regarded as confirmatory evidence of trauma, since he found it in a small percentage of cases of non-traumatic deaths, but the presence of bone marrow in three cases in this series indicates a definite relationship to surgical trauma,

Whilst it is extremely unlikely that the degree of fat embolism evoked by such operative procedures as mitral valvotomy might assume clinical significance, it should, however, be borne in mind that it can occur, and even to such an extent that bone marrow is discharged into the pulmonary vessels.

Florence McKeown, M.D.

Institute of Pathology, Belfast.

REFERENCE

Vance, B. M. (1931). Arch. Surg. (Chicago), 23, 426 